\title{
Effects of Nucleotide Supplementation in Milk Replacer on Small Intestinal Absorptive Capacity in Dairy Calves ${ }^{1}$
}

\author{
S. I. Kehoe, ${ }^{2}$ A. J. Heinrichs, ${ }^{3}$ C. R. Baumrucker, and D. L. Greger \\ Department of Dairy and Animal Science, The Pennsylvania State University, University Park 16802
}

\begin{abstract}
Milk replacer was supplemented with nucleotides and fed to dairy calves from birth through weaning to examine the potential for enhancing recovery of small intestinal function after enteric infection. Three treatments of 23 calves each were fed milk replacer $(10 \%$ body weight/d) supplemented with no nucleotides (C), purified nucleotides $(\mathrm{N})$, or nucleotides from an extract of Saccharomyces cerevisiae (S). Average daily gain, health scores, fecal dry matter, and fecal bacteria were monitored, and blood was analyzed for packed cell volume, glucose, blood urea nitrogen (BUN), and creatinine. Calves were monitored twice daily for fecal score, and $48 \mathrm{~h}$ after increased fecal fluidity was recorded, intestinal function was evaluated by measuring absorption of orally administered xylose $(0.5 \mathrm{~g} / \mathrm{kg}$ of body weight). Packed cell volume of blood was greater for treatment $\mathrm{N}$ for wk 2 and 5 compared with other treatment groups. Four calves per treatment were killed, and intestinal tissue was evaluated for morphology, enzyme activities, and nucleoside transporter mRNA expression. Treatment $\mathrm{S}$ calves had increased abundance of nucleoside transporter mRNA, numerically longer villi, and lower alkaline phosphatase than other groups. Growth measurements and plasma concentrations of glucose, BUN, creatinine, and IgG were not different between treatments; however, BUN-to-creatinine ratio was higher for treatment $\mathrm{N}$, possibly indicating decreased kidney function. There were also no treatment effects on fecal dry matter and fecal bacteria population. However, N-treated calves had the highest detrimental and lowest beneficial bacteria overall, indicating an unfavorable intestinal environment. Supplementation of purified nucleotides did not improve intes-
\end{abstract}

Received October 3, 2007.

Accepted February 19, 2008.

${ }^{1}$ This research was a component of NC-1119, Management Systems to Improve the Economic and Environmental Sustainability of Dairy Enterprises.

${ }^{2}$ Current address: University of Wisconsin-River Falls, Department of Animal Science, 242 Agricultural Science Building, $410 \mathrm{~S}$. 3rd St., River Falls, WI 54022.

${ }^{3}$ Corresponding author: ajh@psu.edu tinal morphology or function and resulted in higher fecal water loss and calf dehydration. Supplementation of nucleotides derived from yeast tended to increase calf intestinal function, provide a more beneficial intestinal environment, and improve intestinal morphology.

Key words: nucleotide, small intestine, milk replacer, dairy calf

\section{INTRODUCTION}

Neonatal diarrhea causes $62 \%$ of annual calf mortality and represents a large economic loss to the dairy industry (Torres-Medina et al., 1985; USDA, 2002). Viral pathogens destroy villus architecture and decrease absorptive surface area of the small intestine (Bridger et al., 1978; Saif et al., 1986; Holland et al., 1992). Loss of epithelial function results in malabsorption of water, $\mathrm{Na}$, and $\mathrm{Cl}$ (Torres-Medina et al., 1985). Continued diarrhea increases the risk of dehydration and hypoglycemia and, if not treated, can lead to death (Clark, 1993; Pensaert and Callebaut, 1994).

Nucleotides are NPN compounds found in many foods such as seafood, legumes, and organ meats. Nucleotides are often called semi-essential nutrients for young animals. Although the body is able to synthesize nucleotides, intestinal tissue that is developing or diseased requires supplemental nucleotides beyond what the body can normally produce (Uauy et al., 1990).

Together, nucleosides, which are nucleotides without attached phosphate groups, and nucleotides enhance intestinal maturation (Uauy et al., 1990) and aid recovery from diarrhea (Kulkarni et al., 1986; Brunser et al., 1994; Bueno et al., 1994) in a variety of species. Recovery of the small intestine after chronic diarrhea is slow and incomplete, yet Bueno et al. (1994) showed that weanling rats suffering from diarrhea recovered after nucleotide supplementation, with intestinal health comparable to rats not challenged with diarrhea. The rats supplemented with nucleotides had fewer intraepithelial lymphocytes, higher microvillous surface area, no cytoplasmic vesiculation, and improved mitochondrial function (Bueno et al., 1994).

Studies of nucleoside transport in the brush border membrane vesicles of veal calves (Theisinger et al., 
2002) showed the nucleotide transporters N1 and N2 (Ngo et al., 2001) were present at an early ages, resulting in the hypothesis that the predominant function was to absorb nucleosides released from desquamated enterocytes. Dietary nucleosides also have been reported to upregulate nucleoside transporter protein in a variety of tissues, including the small intestine. As nucleotide concentrations in the diet increase, ability of enterocytes to absorb nucleosides also increases (Valdes et al., 2000).

Nucleic acids include the nucleotides adenine, thymine, guanine, cytosine, and uracil. Typical dairy cow colostrum contains $3.97 \pm 0.75 \mu \mathrm{mol} / 100 \mathrm{~mL}$ of adenosine monophosphate (AMP), $3.19 \pm 0.41 \mu \mathrm{mol} / 100 \mathrm{~mL}$ of cytosine monophosphate (CMP), and $18.63 \pm 5.01$ $\mu \mathrm{mol} / 100 \mathrm{~mL}$ of uridine monophosphate (UMP); guanosine monophosphate (GMP) was not observed (Gil and Sanchez-Medina, 1981). Dried milk replacer ingredients such as whey, whey protein concentrate, and skim milk usually have very low levels of nucleotides, necessitating nucleotide supplementation in the manufacture of formula to replace milk from humans. However, nucleotide supplementation is not common in the dairy milk replacer industry.

The onset of diarrhea usually requires immediate treatment. In doing so, the ability to decrease the duration or intensity of diarrhea would promote faster recovery, saving the costs associated with time and labor spent on therapy. We hypothesized that providing additional dietary nucleosides would improve intestinal health postchallenge in diarrheic dairy calves. We further hypothesized that addition of nucleotides to the diet of neonatal calves would increase the expression of nucleoside transporter, enabling an increase in the absorption of nucleosides. This would lead to decreased cellular energy expenditure and allow for improved enterocyte regeneration during episodes of diarrhea, resulting in enhanced intestinal function and absorption. Therefore, the objective of this study was to evaluate supplementation of milk replacer with nucleotides on intestinal absorptive function and animal health in preweaned dairy calves.

\section{MATERIALS AND METHODS}

\section{Animals, Housing, and Diet}

The trial utilized 69 Holstein heifer and bull calves (23/treatment, equal numbers of bulls and heifers per treatment) born from September 2005 to April 2006 at the Pennsylvania State University dairy facility and was approved by the University Institutional Animal Care and Use Committee. Treatments were randomly assigned in blocks by birth, and calves were housed in individual $1.2 \times 2.4 \mathrm{~m}$ pens inside a naturally ventilated barn. All calves received $4 \mathrm{~L}$ of colostrum within $6 \mathrm{~h}$ of birth, followed by 4 feedings of transition milk before feeding of milk replacer. Milk replacer was fed at $12 \%$ of birth BW and contained (as-is basis) 22\% CP (all milk protein), $15 \%$ fat (porcine lard), and no additional additives or medication (Akey Inc., Lewisburg, $\mathrm{OH}$ ). Any milk replacer refused was recorded, and only refusals over $1 \mathrm{~L}$ were force-fed. Fresh calf starter (Purina Mills, Camp Hill, PA) was offered ad libitum beginning at $3 \mathrm{~d}$, and intake was recorded daily. Water was offered free-choice daily. Calves were weaned at $5 \mathrm{wk}$ and moved to a group pen at 6 wk of age. Calf starter and milk replacer samples were collected twice monthly and analyzed for nutrient composition (Table 1).

Treatments included a control (C) group fed milk replacer with no supplemental nucleotides, a nucleotide group $(\mathbf{N})$ receiving milk replacer supplemented with purified nucleotides (Lalilab Inc., Raleigh, NC), and a group $(\mathbf{S})$ that was fed milk replacer supplemented with nucleotides derived from cell contents of the yeast species Saccharomyces cerevisiae (NuPro, Alltech Inc., Nicholasville, KY). These were added to the diet of each calf at each feeding depending on the amount of milk replacer fed. Nucleotide treatment consisted of $80 \mu \mathrm{mol} /$ $\mathrm{L}$ of AMP, $64 \mu \mathrm{mol} / \mathrm{L}$ of CMP, and $374 \mu \mathrm{mol} / \mathrm{L}$ of UMP. The $S$. cerevisiae treatment was fed to be similar in concentrations of purified AMP, CMP, and UMP as the purified nucleotide diet and was fed at $0.094 \mathrm{~g} / \mathrm{L}$, which resulted in $79.5 \mu \mathrm{mol} / \mathrm{L}$ of AMP, $60.6 \mu \mathrm{mol} / \mathrm{L}$ of CMP, and $379.4 \mu \mathrm{mol} / \mathrm{L}$ of UMP.

\section{Blood, Health, and Growth Measurements}

All growth measurements (BW, heart girth, hip height, and withers height) were taken at birth and on a weekly basis. One 6 -mL blood sample was collected at $48 \mathrm{~h}$ after birth for total IgG concentration to determine status of passive IgG transfer. Thereafter, jugular blood was sampled weekly $4 \mathrm{~h}$ after a.m. milk feeding. Blood samples were drawn into evacuated blood tubes (Vacutainers, BD, Franklin Lakes, NJ) containing sodium fluoride and potassium oxalate for glucose determinations, and blood tubes containing a clot enhancer were drawn for creatinine analyses. Blood from heparinized samples was drawn into capillary tubes to determine packed cell volume (PCV); the remaining blood was centrifuged for $15 \mathrm{~min}$ at $3,600 \times \mathrm{g}$. Plasma and serum were stored at $-20^{\circ} \mathrm{C}$ until further analysis. Samples were analyzed for BUN (Kit 580, Stanbio Laboratory, San Antonio, TX), plasma glucose (Kit 510, Sigma Chemical Co., St. Louis, MO), and serum creatinine (Kit 420, Stanbio Laboratory). Concentrations of IgG were analyzed using a radial immunodiffusion assay (Bethyl, Montgomery, TX). Health scores were assigned 
Table 1. Nutrient composition of calf starter and milk replacer fed to Holstein calves

\begin{tabular}{|c|c|c|c|c|}
\hline Item $^{1}$ & $\begin{array}{c}\text { Calf } \\
\text { starter }\end{array}$ & SEM & $\begin{array}{l}\text { Milk } \\
\text { replacer }\end{array}$ & SEM \\
\hline Crude protein, \% & 20.1 & 2.01 & 24.11 & 0.06 \\
\hline Fat, \% & - & - & 16.47 & 1.11 \\
\hline Acid detergent fiber, $\%$ & 8.15 & 0.15 & - & - \\
\hline Neutral detergent fiber, $\%$ & 15.15 & 0.98 & - & - \\
\hline Ash, $\%$ & 7.6 & 0.82 & 7.51 & 0.05 \\
\hline Calcium, \% & 0.98 & 0.05 & 0.72 & 0.01 \\
\hline Phosphorus, \% & 0.61 & 0.04 & 0.65 & 0.03 \\
\hline Magnesium, \% & 0.45 & 0.02 & - & - \\
\hline Potassium, \% & 1.18 & 0.05 & - & - \\
\hline Sodium, \% & 0.24 & 0.05 & 0.67 & 0.06 \\
\hline Manganese, ppm & 186.50 & 18.9 & - & - \\
\hline Zinc, ppm & 84.15 & 13.25 & - & - \\
\hline Copper, ppm & 54.00 & 3.2 & - & - \\
\hline Vitamin A, IU/kg ${ }^{2}$ & 6,600 & - & 35,140 & 198 \\
\hline Vitamin D, IU/kg² & 2,200 & - & 7,780 & 311 \\
\hline Vitamin E, IU/kg ${ }^{2}$ & 22 & - & 151 & 0 \\
\hline
\end{tabular}

${ }^{1}$ All values are expressed on a DM basis.

${ }^{2}$ Starter values based on tag of manufacturer.

daily for each calf and evaluated fecal matter, respiration, and general appearance (Lesmeister and Heinrichs, 2004). Fecal scores were based on a 1-to-5 scale where 1 was firm, 5 was watery, and a score of 3 was considered diarrhea. Calves were checked twice daily to monitor for the onset of diarrhea.

\section{Fecal Sampling and Xylose Analysis}

Fecal samples were obtained manually from the rectum of 18 random calves/treatment every other day and analyzed for DM content by drying in an oven at $100^{\circ} \mathrm{C}$ for $48 \mathrm{~h}$. Fecal samples were collected weekly from 7 calves/treatment for the last half of the experiment, and cultures were analyzed for Clostridium perfringens, Lactobacillus acidophilus, and Bifidobacterium spp. Samples were diluted in saline to achieve a workable dilution and incubated overnight anaerobically at $37^{\circ} \mathrm{C}$. Agars used for culture were Remel CDC PEA agar (01048), Anaerobe Systems LMRS agar (AS6429), and Anaerobe Systems Bifidobacterium species agar (AS-6423) based on the methods of Rada and Petr (2000).

Calf fecal scores were assigned twice daily, and $48 \mathrm{~h}$ after the first fecal score $\geq 3$, xylose was fed at $0.5 \mathrm{~g} / \mathrm{kg}$ of BW ( $\mathrm{n}=8$ calves/treatment). Jugular blood samples were obtained in heparinized vacutainers $(\mathrm{BD})$ at 0,1 , 2,3 , and $4 \mathrm{~h}$ after xylose feeding. Serum was centrifuged at $3,600 \times g$ for $15 \mathrm{~min}$ and frozen at $-20^{\circ} \mathrm{C}$ for later analysis of xylose (Merritt and Duelly, 1983).

\section{Intestinal Sampling}

After sampling for xylose absorption, 12 bull calves ( $\mathrm{n}=4$ calves/treatment) were rendered unconscious with a captive bolt gun at the Pennsylvania State University Meats Laboratory and exsanguinated. Immediately after exsanguination, the entire small and large intestines were removed from the body cavity. Within $5 \mathrm{~min}$, two 1-cm sections from each of the duodenum (within $10 \mathrm{~cm}$ of pylorus), jejunum (estimated midpoint of small intestine), and ileum (within $10 \mathrm{~cm}$ of cecum) were rinsed in ice-cold saline and placed in 10\% formalin for morphometric analysis. Sections from these same areas were also rinsed with saline, scraped with a razor blade to obtain a sample ( $3 \mathrm{~g})$, and frozen in liquid $\mathrm{N}$ for enzyme analysis. A sample (1 g) was then collected by scraping and placed in $5 \mathrm{~mL}$ of RNAlater (Ambion, AMS Technology, Cambridgeshire, UK) for examination of nucleoside transporter (SLC28A1; bovine Nacoupled nucleoside transporter, member 1) mRNA abundance by real-time reverse transcription PCR.

\section{Intestinal Analyses}

Intestinal tissue was embedded in paraffin blocks, sectioned at 3 to $6 \mu \mathrm{m}$, and stained with hematoxylin and eosin. Villus lengths and crypt depths were measured for each intestinal section using Scion Image (National Institutes of Health, Bethesda, MD), and means of 20 measurements per segment were used in the calculation for each calf. Only whole villus-crypt units were used for measurement, which included whole rounded villus tips visibly connected to complete crypts that ended near the muscularis mucosal layer.

Intestinal scrapings were analyzed for enzyme activity. Three grams of scrapings was thawed and homogenized in $12 \mathrm{~mL}$ of distilled water while samples were on ice. Alkaline phosphatase was measured as a marker of enterocyte maturation in the upper villus zone 
Table 2. Primers used for quantitative reverse transcription PCR of bovine nucleoside transporter N1 of tissue from Holstein calves

\begin{tabular}{|c|c|c|c|}
\hline Gene & Sequence & $\begin{array}{l}\text { Product size } \\
\quad(\mathrm{bp})^{1}\end{array}$ & $\begin{array}{c}\text { GenBank } \\
\text { accession no. }\end{array}$ \\
\hline \multicolumn{4}{|c|}{ Nucleoside transporter (N1) } \\
\hline Forward & 5'-TCCCTGCCTGAAACTCTG-3' & 248 & BC108101 \\
\hline Reverse & 5'-ACCCTGGTTCTGTTCTGATGAC-3' & & \\
\hline \multicolumn{4}{|l|}{ Cyclophilin } \\
\hline Forward & 5'-GCATACAGGTCCTGGCAT-3' & 236 & AY247029 \\
\hline Reverse & 5'-TGTCCACAGTCAGCAATGGT-3' & & \\
\hline
\end{tabular}

${ }^{1} \mathrm{bp}=$ base pairs of the product.

(Weiser, 1973), and lactase and maltase were measured as brush border markers (Dahlquist and Semenza, 1985). Protein was measured using a Pierce bicinchoninic acid assay with BSA as a standard (Thermo Scientific, Rockford, IL).

\section{PCR}

Total RNA was extracted from duodenum, jejunum, and ileum samples using Versagene RNA Tissue kits (Gentra Systems, Minneapolis, MN). Concentrations of RNA were measured spectrophotometrically in a Shimadzu Bio-Mini (Shimadzu Scientific Instruments, Columbia, MD), and 260:280 $\mathrm{nm}$ absorbance ratios between 1.8 and 2.1 were considered acceptable. Due to low RNA concentrations in the original extractions, samples were concentrated further by Speed-Vac (Savant Instruments Inc., Farmingdale, NY), and concentration measurements were repeated. One microgram of RNA was reverse-transcribed using Protoscript reverse transcriptase (New England BioLabs, Ipswich, MA). Primers were designed with Primer Premier 5 software (Premier Biosoft International, Palo Alto, CA) using a bovine sequence for the intestinal nucleoside transporter (SLC28A1; GenBank accession no. BC108101) that was highly homologous with human gene SLC28A1 (GenBank no. NM004213) identified by basic local alignment search tool (Altschul et al., 1990). Bovine cyclophilin (Table 2) was used as a housekeeping gene to correct for nonspecific changes in mRNA abundance (Greger et al., 2006).

The RT-PCR procedure was performed using DyNamo HS SYBR Green (New England BioLabs) and quantified on an Opticon Monitor System (Genetic Technologies, Miami, FL). Amplification and denaturation conditions used were $95^{\circ} \mathrm{C}$ for $15 \mathrm{~min}$ and 35 repeated cycles of denaturation at $94^{\circ} \mathrm{C}$ for $10 \mathrm{~s}$, annealing at $62^{\circ} \mathrm{C}$ for $30 \mathrm{~s}$, and extension at $72^{\circ} \mathrm{C}$ for $30 \mathrm{~s}$. The melting curve began at 72 to $95^{\circ} \mathrm{C}$ with a heating rate of $0.2^{\circ} \mathrm{C} / \mathrm{s}$ and a final extension step at $72^{\circ} \mathrm{C}$ for 10 min. The PCR product was visualized by agarose gel electrophoresis, and the presence of a single product at the expected molecular weight was confirmed. The product was extracted from the gel and was sequenced at the Pennsylvania State University Nucleic Acid Facility (http://www.huck.psu.edu/stf/naf/home.html). A basic local alignment search tool search was performed to confirm that the sequence was identical with the bovine nucleoside transporter sequence (solute carrier protein; SLC28A1, member 1; GenBank accession no. BC108181).

\section{Statistical Analysis}

Least squares means were analyzed using repeated measures analysis of the mixed procedure of SAS 8.2 (SAS, 2002) with week as a repeated effect. Growth measurements at birth were used as covariates for growth analysis, h 0 was used as a covariate for xylose analysis, and d 0 was used as a covariate for fecal bacteria analysis. The slope between time points for xylose concentrations was also analyzed. The statistical model used for analysis was

$$
\begin{gathered}
\mathrm{Y}_{\mathrm{ijkl}}=\mu+\mathrm{T}_{\mathrm{i}}+\mathrm{W}_{\mathrm{j}}+\mathrm{B}_{\mathrm{k}}+(\mathrm{TW})_{\mathrm{ij}} \\
+(\mathrm{TB})_{\mathrm{ik}}+(\mathrm{WB})_{\mathrm{jk}}+(\mathrm{TWB})_{\mathrm{ijk}}+\operatorname{calf}_{\mathrm{l}}+\mathrm{e}_{\mathrm{ijkl}},
\end{gathered}
$$

where $\mathrm{Y}_{\mathrm{ijkl}}=$ dependent variable; $\mu=$ overall mean; $\mathrm{T}_{\mathrm{i}}=$ fixed effect of treatment $\mathrm{i}$, where $\mathrm{i}=\mathrm{C}, \mathrm{N}$, or $\mathrm{S}$ supplementation; $\mathrm{W}_{\mathrm{j}}=$ repeated measure of week $\mathrm{j} ; \mathrm{B}_{\mathrm{k}}=$ block effect; $(\mathrm{TW})_{\mathrm{ij}}=$ effect of treatment $\times$ week interaction; $(\mathrm{TB})_{\mathrm{ik}}=$ effect of treatment $\times$ block interaction; $(\mathrm{WB})_{\mathrm{jk}}=$ effect of week $\times$ block interaction; $(\mathrm{TWB})_{\mathrm{ijk}}=$ effect of treatment $\times$ week $\times$ block interaction; calf ${ }_{1}=$ random effect of calf $\mathrm{l}$; and $\mathrm{e}_{\mathrm{ijkl}}=$ residual .

Least squares means were determined using the general linear model of SAS 8.2 (SAS, 2002) for intestinal measurements, which included DNA, protein, enzymes, and morphology. The statistical model used for analysis was

$$
\begin{gathered}
Y_{i j k}=\mu+T_{i}+D_{j}+A_{k}+(T D)_{i j} \\
+(T A)_{i k}+(A D)_{k j}+(T A D)_{i j k}+e_{i j k},
\end{gathered}
$$


Table 3. Least squares means of initial and final growth measurements and feed intake for calves fed milk replacer containing no additive $(\mathrm{C})$, purified nucleotides $(\mathrm{N})$, or nucleotides derived from yeast $(\mathrm{S})$

\begin{tabular}{lrrrr}
\hline & \multicolumn{3}{c}{ Treatment } & \\
\cline { 2 - 4 } Item & \multicolumn{1}{c}{$\mathrm{C}$} & $\mathrm{N}$ & $\mathrm{S}$ & SEM \\
\hline No.of calves & \multicolumn{1}{c}{23} & \multicolumn{2}{c}{23} & \\
Weight, kg & & & & \\
Initial, wk 0 & $38.31^{\mathrm{b}}$ & \multicolumn{1}{c}{$41.41^{\mathrm{a}}$} & \multicolumn{1}{c}{$42.09^{\mathrm{a}}$} & 1.12 \\
Final, wk 6 & 57.16 & 58.09 & 57.87 & 1.35 \\
ADG, kg/d & 0.45 & 0.39 & 0.38 & 0.01 \\
Heart girth, cm & & & & \\
Initial & 78.42 & 80.18 & 79.98 & 0.86 \\
Final & 88.65 & 89.64 & 89.71 & 0.71 \\
ADG, cm/d & 0.24 & 0.23 & 0.23 & 0.02 \\
Withers height, cm & & & & \\
Initial & 74.79 & 75.68 & 75.83 & 0.67 \\
Final & 79.64 & 80.38 & 81.22 & 0.48 \\
ADG, cm/d & 0.12 & 0.11 & 0.13 & 0.01 \\
Hip height, cm & & & & \\
Initial & 78.48 & 79.58 & 80.36 & 0.71 \\
Final & 85.06 & 85.51 & 84.12 & 0.97 \\
ADG, kg/d & 0.16 & 0.14 & 0.09 & 0.03 \\
Starter intake, DM g/d & & & & \\
Preweaning & 57.41 & 81.18 & 58.89 & 17.32 \\
Postweaning & 803.63 & 930.94 & 902.35 & 89.56 \\
Milk replacer intake, ${ }^{1}$ kg/d & 4.05 & 3.96 & 4.02 & 0.14 \\
\hline
\end{tabular}

${ }^{\mathrm{a}, \mathrm{b}}$ Different superscripts indicate differences $(P<0.05)$ between treatments.

${ }^{1}$ Preweaning.

where $\mathrm{Y}_{\mathrm{ijk}}=$ dependent variable; $\mu$ = overall mean; $\mathrm{T}_{\mathrm{i}}=$ fixed effect of treatment $\mathrm{i}$, where $\mathrm{i}=\mathrm{C}, \mathrm{N}$, or $\mathrm{S}$ supplementation; $D_{j}=$ fixed effect of $d$ of slaughter $j ; A_{k}=$ fixed effect of intestinal area $\mathrm{k}$, where $\mathrm{k}=$ duodenum, jejunum, or ileum; $(\mathrm{TD})_{\mathrm{ij}}=$ effect of treatment $\times$ day interaction; $(\mathrm{TA})_{\mathrm{ik}}=$ effect of treatment $\times$ area interaction; $(\mathrm{AD})_{\mathrm{kj}}=$ effect of area $\times$ day interaction; $(\mathrm{TAD})_{\mathrm{ijk}}=$ effect of treatment $\times$ area $\times$ day interaction; $e_{i j k}=$ residual.

Least squares means for semiquantitative PCR analysis were obtained using the comparative threshold cycle $\left(2^{-\Delta \Delta \mathrm{CT}}\right)$ method (Livak and Schmittgen, 2001) and analyzed using the MIXED procedure of SAS. The threshold cycle was determined from a log-linear plot of the PCR signal compared with the cycle number. To normalize the PCR reaction for amount of cDNA added to the reverse transcription reactions, cyclophilin, a standard housekeeping gene, was used. Data are presented as fold differences of experimental groups relative to the control group. Data were log-transformed to achieve a normal distribution, and $P$-values were obtained using transformed data.

Least squares means for all analyses were further evaluated if the model was significant at $P<0.05$; trends were discussed at $P<0.15$.
Table 4. Least squares means of fecal bacteria counts of Clostridium perfringens, Lactobacillus acidophilus, and Bifidobacterium spp. (1 $\times 10^{7} \mathrm{cfu} / \mathrm{mL}$ ) for calves fed milk replacer containing no additive (C), purified nucleotides $(\mathrm{N})$, or nucleotides derived from yeast $(\mathrm{S})$

\begin{tabular}{lrrrr}
\hline & \multicolumn{3}{c}{ Fecal bacteria count $\left(1 \times 10^{7} \mathrm{cfu} / \mathrm{mL}\right)$} & \\
\cline { 2 - 3 } & \multicolumn{1}{c}{$\mathrm{C}$} & $\mathrm{N}$ & $\mathrm{S}$ & SEM \\
\hline Bacteria & & & & \\
\cline { 2 - 4 } C. perfringens & 0.57 & 3.02 & 1.64 & 1.23 \\
Week 0 & 0.34 & 2.19 & 2.27 & 1.38 \\
Week 1 & 4.35 & 2.61 & 4.40 & 1.93 \\
Week 2 & 1.01 & 3.91 & 0.00 & 1.54 \\
Week 3 & 0.04 & 0.07 & 0.01 & 0.05 \\
Week 4 & 0.05 & 0.002 & 0.01 & 0.03 \\
Week 5 & & & & \\
L. acidophilus & 30.95 & 114.00 & 281.05 & 140.24 \\
Week 0 & 95.03 & 64.36 & 100.18 & 67.14 \\
Week 1 & 71.68 & 39.69 & 89.86 & 38.35 \\
Week 2 & 116.75 & 112.10 & 147.11 & 51.43 \\
Week 3 & 62.49 & 163.48 & 53.09 & 77.84 \\
Week 4 & 5.99 & 6.64 & 2.71 & 3.05 \\
Week 5 & & & & \\
Bifidobacterium & 56.09 & 152.04 & 117.87 & 48.74 \\
Week 0 & 149.74 & 95.62 & 258.32 & 77.75 \\
Week 1 & 116.08 & 62.12 & 194.78 & 44.94 \\
Week 2 & 69.04 & 128.05 & 136.63 & 83.90 \\
Week 3 & 160.57 & 69.01 & 39.71 \\
Week 4 & 22.13 & 15.73 & 6.18 & 13.53 \\
Week 5 & & & & \\
\hline
\end{tabular}

\section{RESULTS}

\section{Feed Intake and Growth Measurements}

Initial BW at birth was lower for $\mathrm{C}$ calves $(P<0.05)$ even though treatments were randomized (Table 3 ). Therefore, initial BW was used as a covariate in all growth and feed intake analyses and removed if not found significant. Other initial values such as heart girth, withers height, and hip height were not different between treatments. All growth measurements were similar for treatments $\mathrm{C}, \mathrm{N}$, and $\mathrm{S}$ over the 6 -wk period (Table 3).

Feed intake was not different between treatments; however, there was a treatment $\times$ week interaction $(P$ $<0.05$ ) due to group $\mathrm{C}$ tending to consume less starter grain during wk 6 compared with treatment N. No differences in feed intake were detected before weaning, although there was a treatment $\times$ week interaction $(P$ $<0.03$ ) at wk 3 , in which $\mathrm{N}$ tended to be higher than $\mathrm{S}$, and at wk 4, in which $\mathrm{S}$ tended to be higher than $\mathrm{C}$. Postweaning feed intake was not affected by nucleotide treatment.

\section{Fecal Measurements}

Fecal water loss was not different between treatments, and least squares means of DM for treatments $\mathrm{C}, \mathrm{N}$, and $\mathrm{S}$ were $44.0,43.4$, and $44.1 \%$, respectively. Only on d 8 did calves tend to have higher water loss 


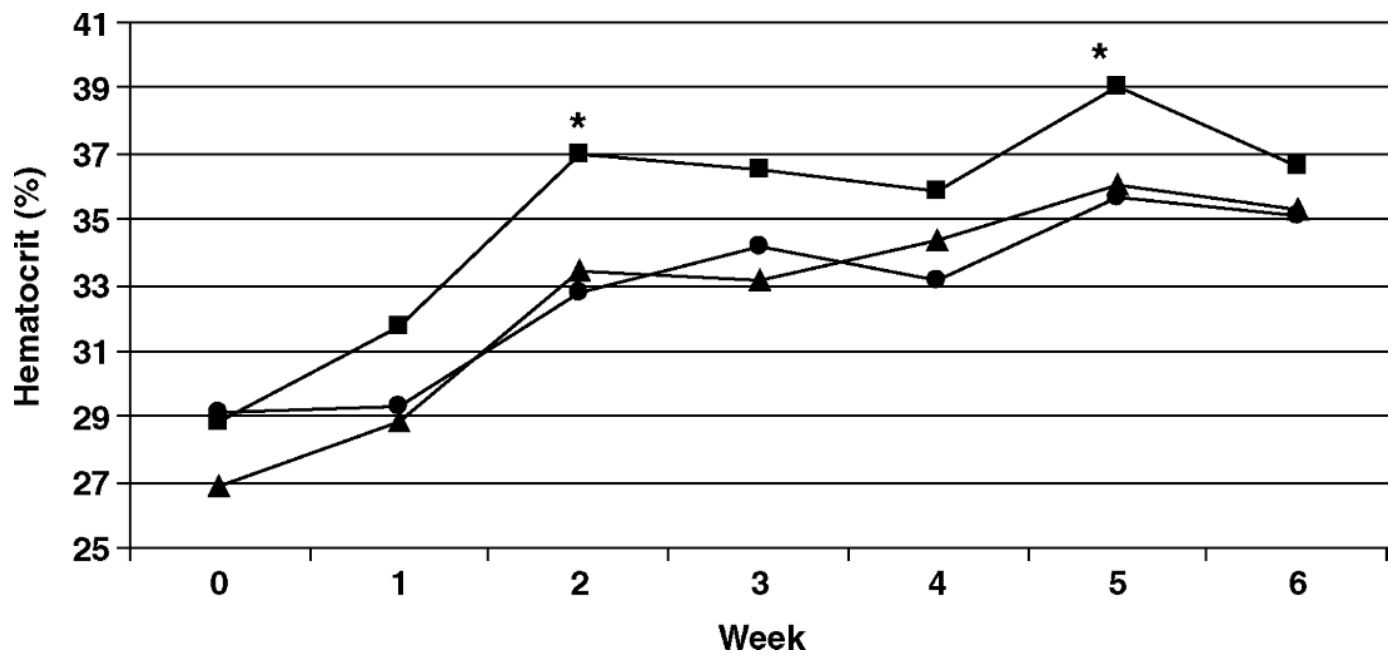

Figure 1. Least squares means of packed cell volume (\%) over time for calves fed milk replacer containing no additive ( $\mathbf{\Delta})$, purified nucleotides $(\square)$, or nucleotides derived from yeast $(\bullet)$. *Indicates differences between treatments at $P<0.05$.

$(P<0.08)$ when provided purified nucleotides $(\mathrm{N})$; water loss was $53.3,42.6$, and $6.2 \%$ for $\mathrm{N}, \mathrm{S}$, and $\mathrm{C}$, respectively.

No differences in the population of fecal bacteria were detected (Table 4). Over the first 6 wk of life, Clostridium perfringens was quantified at 1.1, 2.3, and $1.3 \pm$ $0.5 \times 10^{7}$; Lactobacillus acidophilus averaged 66.4, 79.6, and $110.3 \pm 28.8 \times 10^{7}$; and Bifidobacterium spp. measured 114.8, 106.1, and $125.5 \pm 27.2 \times 10^{7} \mathrm{cfu} / \mathrm{mL}$ of feces, for $\mathrm{C}, \mathrm{N}$, and $\mathrm{S}$, respectively.

\section{Blood Measurements}

The least squares means of PCV were greatest for treatment $\mathrm{N}(35.2 \pm 0.8 \% ; P<0.03)$ and were similar for $\mathrm{C}$ and $\mathrm{S}$ (32.5 and $32.7 \pm 0.8 \%)$. When PCV was analyzed by week (Figure 1), treatment $\mathrm{N}$ was greater during wk 2 and 5 compared with treatments $\mathrm{S}$ and $\mathrm{C}$ $(P<0.02)$. Glucose and BUN were not different between treatments; results were similar using PCV as a covariate. Least squares means of IgG from wk 0 through wk 3 also were similar between treatments (Table 5) both with and without wk 0 as a covariate. Creatinine concentrations were not different between treatments; however, the BUN-to-creatinine ratio, where higher values may indicate inferior kidney function, was numerically highest for the $\mathrm{C}$ treatment.

\section{Xylose Absorption}

Values for xylose concentrations $(\mathrm{mg} / \mathrm{dL})$ represent least squares means adjusted by $\mathrm{h} 0$ as well as initial BW (Figure 2). There were no differences in xylose concentrations between treatments overall; however,
Table 5. Least squares means of blood measurements and health scores for calves fed milk replacer containing no additive $(\mathrm{C})$, purified nucleotides $(\mathrm{N})$, or nucleotides derived from yeast $(\mathrm{S})$

\begin{tabular}{|c|c|c|c|c|}
\hline \multirow[b]{2}{*}{ Item } & \multicolumn{3}{|c|}{ Treatment } & \multirow[b]{2}{*}{ SEM } \\
\hline & $\mathrm{C}$ & $\mathrm{N}$ & $\mathrm{S}$ & \\
\hline Glucose, mg/dL & 227.45 & 214.75 & 235.32 & 13.74 \\
\hline BUN, mg/dL & 10.18 & 8.65 & 9.02 & 0.84 \\
\hline Creatinine, mg/dL & 7.14 & 7.11 & 7.15 & 0.24 \\
\hline BUN:creatinine, mg/mg & 1.43 & 1.22 & 1.26 & - \\
\hline \multicolumn{5}{|l|}{$\mathrm{IgG},{ }^{1} \mathrm{mg} / \mathrm{mL}$} \\
\hline Week 0 & 19.29 & 17.37 & 14.33 & 2.13 \\
\hline Week 1 & 14.48 & 12.41 & 12.64 & 1.48 \\
\hline Week 2 & 10.51 & 11.29 & 8.20 & 1.11 \\
\hline Week 3 & 10.14 & 9.72 & 8.63 & 0.83 \\
\hline Fecal $^{2}$ & 1.29 & 1.24 & 1.26 & 0.02 \\
\hline Total days scouring & 174.00 & 172.00 & 173.00 & - \\
\hline Respiratory $^{2}$ & 1.03 & 1.01 & 1.02 & 0.01 \\
\hline General $^{2}$ & 1.03 & 1.04 & 1.05 & 0.02 \\
\hline MR refusal, ${ }^{3} \mathrm{~mL}$ & 968.4 & $1,114.0$ & $1,279.3$ & 141.73 \\
\hline Days refused $^{4}$ & 23 & 51 & 25 & 一 \\
\hline Calves refused ${ }^{5}$ & 12 & 13 & 13 & 一 \\
\hline \multicolumn{5}{|l|}{ Oral rehydration treatment } \\
\hline Days treated & 68 & 52 & 66 & - \\
\hline Calves treated & 13 & 12 & 14 & - \\
\hline \multicolumn{5}{|l|}{ Antibiotic treatment } \\
\hline Days treated & 17 & 13 & 24 & - \\
\hline Calves treated & 8 & 7 & 11 & - \\
\hline
\end{tabular}

${ }^{1}$ Samples for wk 0 IgG were taken at $48 \mathrm{~h}$ after birth. All other samples were taken weekly from day of birth.

${ }^{2}$ Scored on a scale of 1 to 5 as described by Lesmeister and Heinrichs (2004). Lower numbers indicate more normal calf health.

${ }^{3}$ Average amount of milk replacer (MR) refused per occurrence (in $\mathrm{mL}$ per treatment).

${ }^{4}$ Number of days each treatment refused to drink milk replacer and needed to be fed by bottle or forced esophageal feeder.

${ }^{5}$ Number of calves in each treatment that refused to drink milk replacer and needed to be fed by bottle or esophageal feeder. 


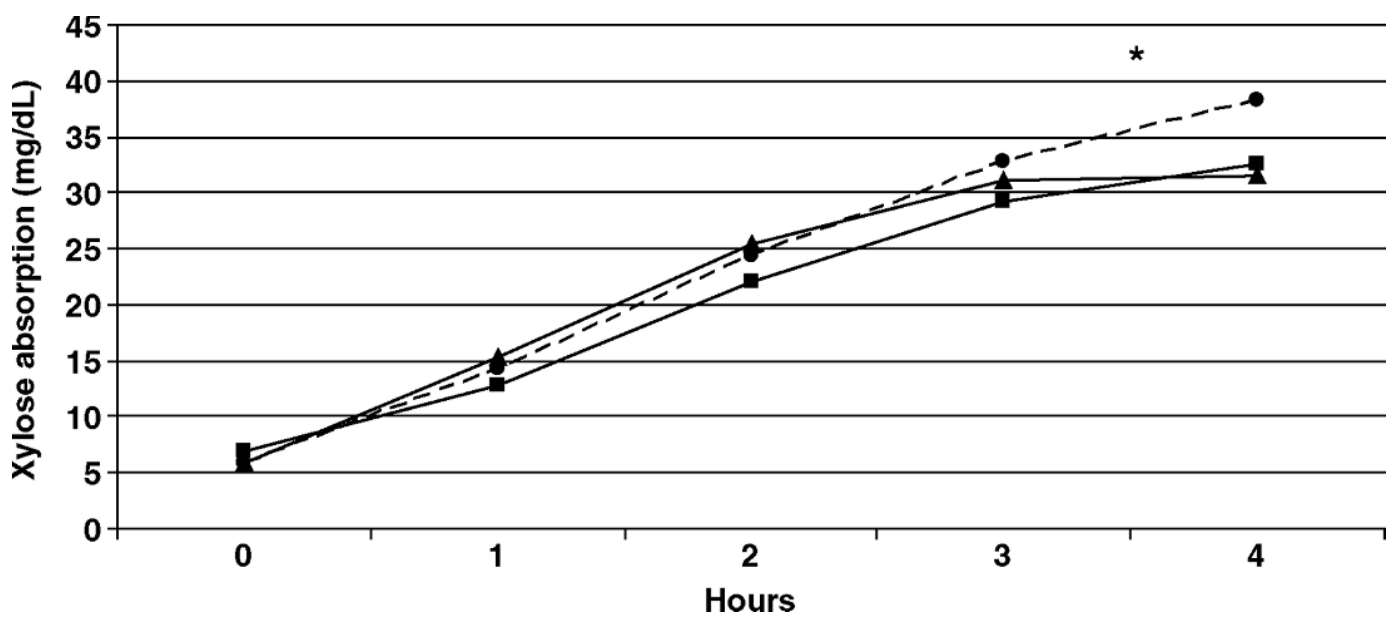

Figure 2. Least squares means of xylose concentration $(\mathrm{mg} / \mathrm{dL})$ over the $4 \mathrm{~h}$ after dosing for calves fed milk replacer containing no additive $(\boldsymbol{\Delta})$, purified nucleotides $(\boldsymbol{\square})$, or nucleotides derived from yeast $(\bullet)$. ${ }^{*}$ Indicates a trend between the $\boldsymbol{\Delta}$ and $\bullet$ treatments $(P<0.13)$.

treatment $\mathrm{S}$ tended to be higher than $\mathrm{C}$ when the slope from $\mathrm{h} 3$ to 4 was investigated $(P<0.13)$.

\section{Health Measurements}

Amount of milk replacer refused, number of calves that refused to drink, and number of calves treated with oral rehydration solution or antibiotics were similar for all groups (Table 5). The $\mathrm{N}$ treatment was highest in number of days that calves refused to drink milk replacer but lowest for number of days treated with oral rehydration solution and antibiotics. However, health scores were not different between treatments (Table 5). All calves experienced diarrhea (fecal score $\geq 3$ ) at least once during the trial, but scores were not different by treatment. The highest number of days scouring and treatment days were determined typical for the time of year in this particular calf barn. There was a significant week effect $(P<0.01)$, in which fecal scores decreased over time, as well as a treatment $\times$ week effect $(P<$ 0.02 ). During wk 2,3 , and $4, \mathrm{C}$ had significantly higher fecal scores than S and N. During wk 3, S had significantly higher fecal scores than N. Respiratory scores had a significant week effect $(P<0.01)$, in which scores increased over time. There was also a trend for a treatment $\times$ week interaction $(P<0.07)$, in which $\mathrm{C}$ fecal scores were higher than $\mathrm{N}$ during wk 3,4 , and 5 . Treatment $\mathrm{S}$ had greater respiratory scores that increased at a greater rate during wk 4 and 5, when compared with treatment $\mathrm{C}$. General appearance scores among calves were similar in all treatments but were different across weeks $(P<0.01)$. Scores decreased over time, and there was a treatment $\times$ week effect $(P<0.01)$, in which treatment $\mathrm{S}$ increased at a higher rate over wk 5 and 6 compared with other treatments.

\section{Intestinal Measurements}

Weights and measurements of intestinal tissue, spleen, and liver were not different between treatments (data not shown). Least squares means of DNA (mg/ $\mathrm{mL}$ ) by area of intestinal tissue tended to be higher for the duodenum compared with the ileum $(P<0.07)$, but treatments were not different (Table 6). However, DNA in milligrams per gram of wet tissue differed by intestinal area $(P<0.02)$, tended to vary by treatment $(P<$ $0.14)$, and had a treatment $\times$ area interaction $(P<0.03)$. Concentrations of DNA per gram of wet tissue tended to be higher for treatment $\mathrm{S}$ compared with treatment $\mathrm{C}$ and higher for the duodenum compared with both the jejunum and ileum $(P<0.03$ and $P<0.01$, respectively). Least squares means for protein were not different between treatments or area of intestinal tissue. Activity of alkaline phosphatase (units/mL) was much higher in duodenal tissue $(P<0.01)$ than in jejunal and ileal tissue (Table 6). There was also a tendency for an effect of nucleotide treatment; $\mathrm{C}$ and $\mathrm{N}$ had higher activity in the duodenum than $\mathrm{S}(P<0.08)$. Although no other trends were apparent, $\mathrm{N}$ was numerically lowest for both jejunum and ileum sections in alkaline phosphatase activity. Analysis of alkaline phosphatase activity per gram of wet tissue showed increased activity in the duodenum compared with jejunum and ileum $(P<0.01)$. In both the jejunum and ileum, activity was numerically highest for $\mathrm{C}$ and lowest for $\mathrm{N}$.

Maltase (units/mL) least squares means were not different between treatments but tended to be higher for duodenum $(P<0.09)$. Maltase per milligram of protein tended to be lowest $(P<0.06)$ in the duodenum. Differences in lactase activity were not detected (Table 6). 
Table 6. Least squares means of intestinal and enzyme measurements by treatment [calves fed milk replacer containing no additive $(\mathrm{C})$, purified nucleotides $(\mathrm{N})$, or nucleotides derived from yeast $(\mathrm{S})]$ and by area of the intestine [duodenum (D), jejunum (J), and ileum (I)]

\begin{tabular}{|c|c|c|c|c|c|c|c|}
\hline \multirow[b]{2}{*}{ Item } & \multicolumn{3}{|c|}{ Treatment } & \multicolumn{3}{|c|}{ Intestinal area } & \multirow[b]{2}{*}{ SEM } \\
\hline & $\mathrm{C}$ & $\mathrm{N}$ & $\mathrm{S}$ & $\mathrm{D}$ & $\mathrm{J}$ & I & \\
\hline Maltase ${ }^{1} \mathrm{U}$ & 0.157 & 0.106 & 0.104 & $0.036^{\mathrm{b}}$ & $0.162^{\mathrm{a}}$ & $0.169^{\mathrm{a}}$ & 0.028 \\
\hline Lactase, ${ }^{1} \mathrm{U}$ & 0.296 & 0.202 & 0.249 & 0.069 & 0.341 & 0.336 & 0.088 \\
\hline Alkaline phosphatase,${ }^{1} \mathrm{U}$ & $14.24^{\mathrm{x}}$ & $11.52^{x}$ & $10.14^{\mathrm{y}}$ & $29.93^{\mathrm{a}}$ & $5.76^{\mathrm{b}}$ & $0.22^{\mathrm{b}}$ & 4.19 \\
\hline Protein, mg/g of wet tissue & 50.49 & 57.41 & 50.04 & 55.64 & 52.63 & 49.68 & 1.07 \\
\hline DNA, mg/g of wet tissue & $2.54^{\mathrm{yz}}$ & $3.17^{\mathrm{y}}$ & $3.37^{\mathrm{x}}$ & $3.74^{\mathrm{a}}$ & $2.79^{b}$ & $2.55^{\mathrm{b}}$ & 0.29 \\
\hline DNA:protein ratio, mg/mg & 0.43 & 0.45 & 0.51 & 0.52 & 0.45 & 0.42 & 0.06 \\
\hline Relative expression ${ }^{2}$ & 1.0 & 3.5 & 7.0 & 1.0 & 2.8 & 5.2 & \\
\hline Villus heights, $\mu \mathrm{m}$ & 228.05 & 202.75 & 231.65 & 245.98 & 229.45 & 187.03 & 20.54 \\
\hline Crypt depths, $\mu \mathrm{m}$ & 122.38 & 130.99 & 121.59 & 130.09 & 122.87 & 121.99 & 7.91 \\
\hline \multicolumn{8}{|l|}{ Duodenum, $\mu \mathrm{m}$} \\
\hline Villus heights & 244.63 & 211.96 & 281.34 & - & - & - & 37.55 \\
\hline Crypt depths & 137.33 & 126.49 & 126.44 & - & - & - & 14.77 \\
\hline Villus:crypt & 1.78 & 1.68 & 2.23 & - & - & - & - \\
\hline \multicolumn{8}{|l|}{ Jejunum, $\mu \mathrm{m}$} \\
\hline Villus heights & 287.32 & 182.95 & 218.08 & - & - & - & 37.63 \\
\hline Crypt depths & 109.89 & 146.68 & 112.05 & - & - & - & 11.83 \\
\hline Villus:crypt & 2.61 & 1.24 & 1.95 & - & - & - & - \\
\hline \multicolumn{8}{|l|}{ Ileum, $\mu \mathrm{m}$} \\
\hline Villus heights & 152.21 & 213.35 & 195.53 & - & - & - & 32.35 \\
\hline Crypt depths & 119.92 & 119.80 & 126.97 & - & - & - & 14.77 \\
\hline Villus:crypt & 1.27 & 1.78 & 1.54 & - & - & - & - \\
\hline
\end{tabular}

${ }^{\mathrm{a}, \mathrm{b}}$ Different superscripts indicate differences $(P<0.05)$ between intestinal areas.

${ }^{\mathrm{x}-\mathrm{z}}$ Different superscripts indicate differences $(P<0.15)$ between treatments.

${ }^{1} \mathrm{U}=$ Units of activity per minute per milligram of protein.

${ }^{2}$ Relative SLC28A1 expression $=$ target $\Delta \Delta \mathrm{C}(\mathrm{T})$ value of treatments relative to control $\Delta \Delta \mathrm{C}(\mathrm{T})($ comparative threshold cycle method) treatment.

Morphology of intestinal tissue was not different between treatments or area of intestine (Table 6). Overall, villi were longer $(P<0.01)$ than crypts $(219.64 \pm 9.65$ and $125.24 \pm 9.47 \mu \mathrm{m}$, respectively). Villi lengths were only numerically different by area, where villi lengths were highest in duodenum and lowest in ileum; crypt depths were only slightly numerically higher in duodenum and lower in ileum.

\section{Nucleoside Transporter mRNA Abundance}

Nucleoside transporter mRNA (SLC28A1) abundance (Table 6) approached significance between treatments $(P<0.06)$ where treatment $\mathrm{S}$ mRNA abundance was higher relative to mRNA abundance of treatment $\mathrm{C}$ and $\mathrm{N}(P<0.03)$. In the jejunum (Figure 3$), \mathrm{S}$ treatment had greater mRNA abundance relative to $\mathrm{C}(P<$ $0.04)$ and $\mathrm{N}(P<0.14)$, and treatment $\mathrm{N}$ had greater mRNA abundance in the ileum relative to $\mathrm{C}(P<0.05)$ but not $\mathrm{S}$. And overall, treatment $\mathrm{S}$ had greater mRNA abundance relative to $\mathrm{C}$ both in the jejunum $(P<0.04)$ and in the ileum $(P<0.03)$.

\section{DISCUSSION}

Nucleotides are known as semi-essential nutrients, because, although the body is able to synthesize them endogenously, disease and rapid growth may increase their requirement. Supplementation of nucleotides in rats, pigs, and humans has increased intestinal integrity, improved intestinal morphology, and reduced diar-

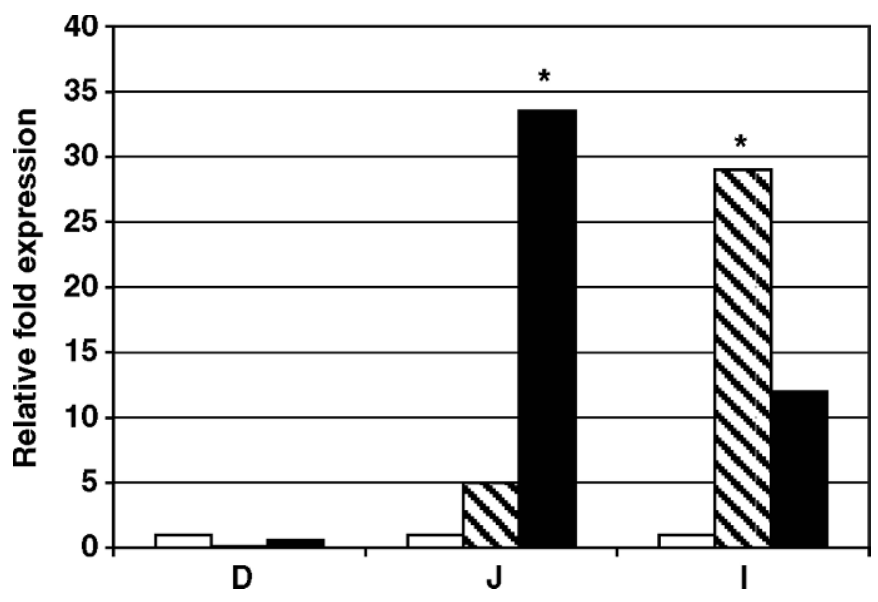

Figure 3. Relative fold expression of mRNA for treatments compared with control for the nucleoside transporter (GenBank number BC108101) by area of intestine ( $\mathrm{D}=$ duodenum; $\mathrm{J}=$ jejunum; $\mathrm{I}=$ ileum). Calves were fed milk replacer containing no additive (control; set at 1.0; open bars), purified nucleotides (striped bars), or nucleotides derived from yeast (solid bars). *Indicates significance at $P$ $<0.05$. 
rhea (Kulkarni et al., 1986; Uauy et al., 1990; Brunser et al., 1994).

In the present study, there were no differences in intestinal function as indicated by similar xylose uptake from the small intestine between treatment groups. Xylose concentrations in the current study peaked at 31 to $38 \pm 3.9 \mathrm{mg} / \mathrm{dL}$. Healthy, colostrum-fed calves reached peak xylose concentrations near $55 \mathrm{mg} /$ dL (Schottstedt et al., 2005). Whereas in other studies, xylose concentrations in calves with intestinal damage peaked at 45 to $75 \mathrm{mg} / \mathrm{dL}$ (Holland et al., 1992; Nappert et al., 2000). Peak xylose concentrations in this study were lower than other studies, indicating that intestinal tissue was challenged as if calves were purposefully infected. Treatment with yeast cell contents slightly improved intestinal xylose absorption, indicating improved function of enterocytes or perhaps increased surface area due to longer villi and higher amounts of DNA per milligram of wet tissue for the $\mathrm{S}$ treatment group.

Fecal bacteria concentrations were high during this time although not different between treatments. Others have reported that supplementing piglets with nucleosides during the postweaning period may positively enhance the intestinal environment by increasing lactobacilli and bifidobacteria while decreasing clostridia (Mateo et al., 2004).

Smith (1965) reported concentrations of lactobacilli in feces for healthy calves approximately $12 \mathrm{~d}$ of age ranging from 9 to $10 \times 10^{10}$, which is approximately 1 billion cfu/mL. In the current study, lactobacilli for the first 2 wh ranged from 30 to $114 \times 10^{7} \mathrm{cfu} / \mathrm{mL}$. All calves experienced diarrhea between 8 and $16 \mathrm{~d}$, and C. perfringens concentrations peaked at wk 2 for $\mathrm{C}$ and $\mathrm{S}$ treatments and at wk 3 for $\mathrm{N}$ treatment. Bifidobacteria species peaked at wk 1 for S, wk 3 for $\mathrm{C}$, and wk 4 for N. Lactobacillus acidophilus peaked at wk 3 for $\mathrm{C}$ and $\mathrm{S}$ and wk 4 for $\mathrm{N}$. The patterns of these bacterial concentrations indicate that the presence of $C$. perfringens inhibited the growth of bifidobacteria species and L. acidophilus in all treatments, which could have altered the intestinal environment and led to increased diarrhea. Xylose absorption also could have been affected by the altered intestinal environment due to high bacterial counts.

Bacterial concentrations in the current study also coincided with weaning. During wk 4, concentrations of $L$. acidophilus and bifidobacteria species were high, and upon weaning at $5 \mathrm{wk}$ of age, bacterial counts decreased dramatically. Before weaning, calves are the most susceptible to enteric disease, but risks decrease as rumen function and starter intake increase.

Volume of milk replacer refused, an indicator of general well-being, was not different between treatments. The $\mathrm{N}$ treatment had similar numbers of calves that refused to drink compared with other treatments; however, calves on the $\mathrm{N}$ treatment also had the highest number of days milk replacer was refused. Similar numbers of calves were treated with oral rehydration solution, but the S group had more calves treated with antibiotics for more days than the $\mathrm{N}$ or $\mathrm{C}$ treatments. Although the $\mathrm{N}$ calves were treated with antibiotics and rehydration therapy the least number of days, their status for dehydration and intestinal measurements of diarrhea indicate that this group had infections, but these were not severe enough to warrant treatment. Although the number of days treated was reduced, the higher number of days that calves refused milk replacer on the $\mathrm{N}$ treatment indicated that calves were not quick to recover but bordered on illness for longer periods of time.

The lack of effect of nucleotide supplementation on growth measurements is not surprising. When nucleotide-free diets were fed to rats, growth rates were enhanced once nucleotides were reintroduced into the diet (Lopez-Navarro et al., 1996); however, rats fed dietary nucleotides compared with rats fed a normal diet without extra supplementation showed no enhanced growth rates (Clifford and Story, 1976).

Blood measurements, including glucose, BUN, and creatinine, also were not different between treatments. Katoh et al. (2005) reported a decrease in plasma glucose levels of Holstein bull calves fed UMP; however, UMP concentrations fed were higher $(2 \mathrm{~g} / \mathrm{d})$ than the current study, which was supplemented at $0.12 \mathrm{~g} / \mathrm{L}$ twice daily (calves of average BW received $1.2 \mathrm{~g} / \mathrm{d}$ of UMP). Although differences were found in glucose levels, organ weights were not different as reported by Katoh et al. (2005), which supports the current lack of differences between treatments for liver and spleen weights.

Enzyme activities were affected by area of the intestine but not by treatments. Enzyme activity is usually greatest in the duodenum and decreases progressively throughout the intestine. Levels of alkaline phosphatase were within normal ranges of calves approximately 5 to $10 \mathrm{~d}$ of age; however, maltase and lactase were higher than previously reported (Le Huerou et al., 1992). Also, lactase activity was lowest in duodenum and highest in jejunum and ileum, which is not supported by other work and may have been affected by high bacterial counts that changed the intestinal environment and thus altered enzyme function.

It is difficult to compare the present results with those of other studies, because many nucleotide experiments compare supplemented animals to those fed diets deprived of nucleotides; nucleotide-free diets may enhance differences between treatments. Research studies that determine the effects of animals fed normal, 
nucleotide-containing diets compared with animals supplemented with extra nucleotides, found no differences in enzyme activities (Carver et al., 1993). Other work using calves did not find differences in DNA, protein, or enzyme activities except for higher ileal DNA and lower aminopeptidase- $\mathrm{N}$ for nucleotide-fed calves (Oliver et al., 2005).

The current study reported significantly higher DNA concentrations per wet tissue weight in duodenum compared with jejunum and ileum, which is supported by other work (Uauy et al., 1990; Le Huerou et al., 1992; Buhler et al., 1998). Although not significant, DNA concentrations for the $\mathrm{S}$ treatment were numerically higher than both $\mathrm{N}$ and $\mathrm{C}$ treatments, perhaps indicating a greater proliferation of cells that may be due to longer intestinal villi.

The $\mathrm{S}$ treatment had numerically greater lengths of villi in the duodenum and ileum. Alkaline phosphatase, which is a marker of the maturity of enterocytes reaching villous tips, was lower for the $\mathrm{S}$ treatment. This may indicate that enterocytes reaching the villous tips were less mature than other treatments, which may be caused by a faster turnover rate. The $\mathrm{S}$ treatment had longer villi and higher concentrations of DNA per gram of wet tissue, which indicates more enterocytes either due to longer villi containing more cells or higher turnover as indicated by the lower maturity of cells at villous tips. Although this would normally cause increased incidence of diarrhea, treatment with yeast cell contents may have ameliorated these effects considering the $\mathrm{S}$ group had a slightly improved intestinal xylose uptake, more beneficial intestinal bacteria, and normal PCV levels.

Calves supplemented with yeast cell contents had the highest expression of nucleoside transporter. The highest mRNA abundance occurred in the jejunum and ileum compared with control calves, which is different than that reported by Theisinger et al. (2002), who found the highest nucleoside transporter activity in the duodenum and decreasing activity through to the distal intestine. However, the Theisinger et al. (2002) studies reported specific nucleoside uptakes with brush border membrane vesicles conducted in vitro. Furthermore, other studies used purified nucleotides, whereas in the current study, the $\mathrm{S}$ treatment contained nucleotides within yeast cell contents, which may affect differences in transporter expression. The highest gene expression of the nucleoside transporter for the $\mathrm{N}$ group was in the ileum, in contrast to Theisinger et al. (2002). In the current study, calves were sacrificed during wk 2 to 3 when $C$. perfringens levels were highest, which may have altered the intestinal environment and nucleotide receptor activity.
Our data represents mRNA abundance and not presence of the protein, whereas the Theisinger study measured protein transport observed in vitro and with individual nucleosides. Comparisons are difficult to interpret, but if mRNA expression is assumed to be related to active protein, then the yeast cell extract would be expected to increase transporters expressed in the enterocytes. The $\mathrm{S}$ treatment had a 7 -fold increase in mRNA abundance compared with the control group, suggesting increased transporter protein. Both treatment groups that received nucleotide supplementation had higher fecal bacteria counts of C. perfringens during the first week of life compared with calves not receiving any nucleotides. This could indicate that $C$. perfringens bacteria were utilizing part of the purified nucleotide supply from the beginning of supplementation, which may explain the higher PCV, fecal water loss, and inferior intestinal morphology found in the $\mathrm{N}$ treatment when compared with the other treatments. Although C. perfringens counts were also higher during the first week of life for the $\mathrm{S}$ treatment, L. acidophilus and bifidobacteria species were higher as well, which may have somewhat ameliorated the effects of higher clostridia counts. Although bacteria may have been utilizing part of the nucleotide supply, the increase in expression of nucleoside transporter indicates that there were enough nucleotides present in the intestinal lumen to stimulate uptake by increasing expression of the nucleoside transporter.

Although expression of the nucleotide transporter was lower in the ileum for the calves fed S treatment when compared with the $\mathrm{N}$ treatment, all the other beneficial effects seen in $\mathrm{S}$ treatment calves and not in $\mathrm{N}$ treatment calves indicate that absorption of nucleotides in the ileum may be too late to have a significant effect on intestinal health and hydration of calves. This may be due to intestinal bacteria utilizing the nucleotides for self-promotion as well as the greater nutrient absorption that occurs in the jejunum. Enterocytes in the ileum will not have as great of an effect on absorption as enterocytes in the jejunum.

In the current study, amounts of nucleotides fed were based on values determined from 0 - to 1 -d colostral secretions by Gil and Sanchez-Medina (1981). In 1996, infant formula was reformulated to contain 2.99 AMP, 5.35 CMP, $0.96 \mathrm{GMP}$, and 3.73 UMP ( $\mu \mathrm{mol} / \mathrm{L})$. Recently, some work has been conducted to supplement dairy calves with nucleotides. Oliver et al. (2003) fed 0.04 AMP, $1.14 \mathrm{CMP}, 0.48 \mathrm{GMP}$, and $10.3 \mathrm{UMP}(\mu \mathrm{mol} / \mathrm{kg}$ of BW) daily. Therefore, assuming an average $55-\mathrm{kg}$ calf, amounts fed were 2.2 AMP, 62.7 CMP, 26.4 GMP, 35.2 inosine monophosphate (IMP), and 566.5 UMP $(\mu \mathrm{mol} / \mathrm{d})$. In the study by Oliver et al. (2003), there were 
no differences between treatment, and this likely was due to these levels being very low.

Treatment $\mathrm{N}$ had higher dehydration incidence during wk 2 and 5 compared with $\mathrm{C}$ and S. Fecal water loss also tended to be higher for $\mathrm{N}$ during $\mathrm{d} 8$, and the BUN-to-creatinine ratio indicated decreased kidney function due to higher dehydration. Treatment $\mathrm{N}$ also had the lowest concentrations of bifidobacteria, which never attained as high a peak as the other treatments. Even though treatment S had lower enterocyte maturity and higher sloughing of cells, PCV levels were normal, intestinal function was better, intestinal villi were longer, and DNA per milligram of wet tissue concentrations were higher.

The concentrations fed in the current study were almost double that of colostrum values. However, further increasing concentrations may increase the supply of nucleotides not utilized by $C$. perfringens bacteria to intestinal transporters. The method of administering the treatment should also be evaluated as to whether feeding in milk replacer provides the best results. Nucleoside uptake in the intestine may be decreased in the presence of glucose (Theisinger et al., 2002); however, supplementation in milk remains the least labor-intensive method available to calf raisers.

\section{CONCLUSIONS}

Neonatal calf diarrhea is often a persistent problem on dairy farms. Research with other species has shown that dietary supplementation with nucleotides improves intestinal morphology and decreases diarrhea. In the current study, calves supplemented with purified nucleotides had higher dehydration, lower beneficial bacteria concentrations in feces, and similar intestinal xylose absorption to untreated calves. Feeding dietary nucleotides upregulated transporter mRNA abundance in the calf intestine; measuring nucleoside transporter (N1) expression may be a useful means to monitor intestinal activity. Calves supplemented with yeast cell contents had longer intestinal villi and a more beneficial intestinal environment due to higher concentrations of L. acidophilus and bifidobacteria. Further evaluation of diet supplementation with yeast cell contents may lead to better calf health by improving intestinal morphology and function.

\section{ACKNOWLEDGMENTS}

Partial support for this research was provided by the Pennsylvania Department of Agriculture Animal Health Commission, with additional support for nucleotides from Alltech Inc. (Nicholasville, KY). The technical support of Maria Long and editorial assistance pro- vided by Coleen Jones (Dept. Dairy Anim. Sci., Penn State) are greatly appreciated.

\section{REFERENCES}

Altschul, S. F., W. Gish, W. Miller, E. W. Myers, and D. J. Lipman. 1990. Basic local alignment search tool. J. Mol. Biol. 215:403-410.

Bridger, J. C., G. N. Woode, and A. Meyling. 1978. Isolation of coronaviruses from neonatal calf diarrhoea in Great Britain and Denmark. Vet. Microbiol. 3:101-113.

Brunser, O., J. Espinoza, M. Araya, S. Cruchet, and A. Gil. 1994. Effect of dietary nucleotide supplementation on diarrhoeal disease in infants. Acta Paediatr. 83:188-191.

Bueno, J., M. Torres, A. Almendros, R. Carmona, M. C. Nunez, A. Rios, and A. Gil. 1994. Effect of dietary nucleotides on small intestinal repair after diarrhoea. Histological and ultrastructural changes. Gut 35:926-933.

Buhler, C., H. Hammon, G. L. Rossi, and J. W. Blum. 1998. Small intestinal morphology in eight-day-old calves fed colostrum for different durations or only milk replacer and treated with longR3-insulin-like growth factor I and growth hormone. J. Anim. Sci. 76:758-765.

Carver, J. D., S. Bustamante, D. Novak, and L. Barness. 1993. Dietary nucleotides may act as growth factors in liver and intestine. FASEB J. 7:A643 (Abstr.).

Clark, M. A. 1993. Bovine coronavirus. Br. Vet. J. 149:51-70.

Clifford, A. J., and D. L. Story. 1976. Levels of purines in foods and their metabolic effects in rats. J. Nutr. 106:435-442.

Dahlquist, A., and G. Semenza. 1985. Disaccharidases of small-intestinal mucosa. J. Pediatr. Gastroenterol. Nutr. 4:857-865.

Gil, A., and F. Sanchez-Medina. 1981. Acid-soluble nucleotides of cow's, goat's and sheep's milks, at different stages of lactation. J. Dairy Res. 48:35-44.

Greger, D. L., C. Philipona, and J. W. Blum. 2006. Ontogeny of mRNA abundance of nuclear receptors and nuclear receptor target genes in young cattle. Domest. Anim. Endocrinol. 31:76-87.

Holland, R. E., S. M. Boyle, T. H. Herdt, S. D. Grimes, and R. D. Walker. 1992. Malabsorption of vitamin A in preruminating calves infected with Cryptosporidium parvum. Am. J. Vet. Res. 53:1947-1952.

Katoh, K., K. Yoshioka, H. Hayashi, T. Mashiko, M. Yoshida, Y. Kobayashi, and Y. Obara. 2005. Effects of 5'-uridylic acid feeding on postprandial plasma concentrations of $\mathrm{GH}$, insulin and metabolites in young calves. J. Endocrinol. 186:157-163.

Kulkarni, A. D., W. C. Fanslow, F. B. Rudolph, and C. T. Van Buren. 1986. Effect of dietary nucleotides on response to bacterial infections. JPEN 10:169-171.

Le Huerou, I., P. Guilloteau, C. Wicker, A. Mouats, J. Chayvialle, C. Bernard, J. Burton, R. Toullec, and A. Puigserver. 1992. Activity distribution of seven digestive enzymes along small intestine in calves during development and weaning. Dig. Dis. Sci. 37:40-46.

Lesmeister, K. E., and A. J. Heinrichs. 2004. Effects of corn processing on growth characteristics, rumen development, and rumen parameters in neonatal dairy calves. J. Dairy Sci. 87:3439-3450.

Livak, K. J., and T. D. Schmittgen. 2001. Analysis of relative gene expression data using real-time quantitative PCR and the $2^{-\Delta \Delta \mathrm{CT}}$ method. Methods 25:402-408.

Lopez-Navarro, A. T., M. A. Ortega, J. Peragon, J. D. Bueno, A. Gil, and A. Sanchez-Pozo. 1996. Deprivation of dietary nucleotides decreases protein synthesis in the liver and small intestine of rats. Gastroenterology 110:1760-1769.

Mateo, C. D., R. I. Dave, and H. H. Stein. 2004. Effect of supplemental nucleosides for newly weaned pigs. J. Anim. Sci. 82(Suppl. 2):71. (Abstr.)

Merritt, A. M., and P. Duelly. 1983. Phloroglucinol microassay for plasma xylose in dogs and horses. Am. J. Vet. Res. 44:2184-2185.

Nappert, G., J. M. Barrios, G. A. Zello, and J. M. Naylor. 2000. Oral rehydration solution therapy in the management of children with rotavirus diarrhea. Nutr. Rev. 58:80-87.

Ngo, L. Y., S. D. Patil, and J. D. Unadkat. 2001. Ontogenic and longitudinal activity of $\mathrm{Na}(+)$-nucleoside transporters in the hu- 
man intestine. Am. J. Physiol. Gastrointest. Liver Physiol. 280:G475-G481.

Oliver, C. E., M. L. Bauer, C. M. De Jesus Arias, W. L. Keller, and C. S. Park. 2003. Influence of dietary nucleotides on calf health. J. Anim. Sci. 86(Suppl. 1):136. (Abstr.)

Oliver, C. E., C. De Jesus Arias, W. L. Keller, M. L. Bauer, and C. S. Park. 2005. Small intestinal composition and hydrolytic activity in neonatal calves fed nucleotides. J. Dairy Sci. 88(Suppl. 1):385.

Pensaert, M. B., and P. Callebaut. 1994. Bovine coronavirus infection. In Infectious Diseases of Livestock. Univ. Press, Oxford, UK.

Rada, V., and J. Petr. 2000. A new selective medium for the isolation of glucose non-fermenting bifidobacteria from hen caeca. J. Microbiol. Methods 43:127-132.

Saif, L. J., D. R. Redman, P. D. Moorhead, and K. W. Theil. 1986. Experimentally induced coronavirus infections in calves: Viral replication in the respiratory and intestinal tracts. Am. J. Vet. Res. 47:1427-1432.

SAS. 2002. User's Guide: Statistics. SAS Inst. Inc., Cary, NC.

Schottstedt, T., C. Muri, C. Morel, C. Philipona, H. M. Hammon, and J. W. Blum. 2005. Effects of feeding vitamin A and lactoferrin on epithelium of lymphoid tissues of intestine of neonatal calves. J. Dairy Sci. 88:1050-1061.
Smith, H. W. 1965. The development of the flora of the alimentary tract in young animals. J. Pathol. Bacteriol. 90:495-505.

Theisinger, A., B. Grenacher, K. S. Rech, and E. Scharrer. 2002. Nucleosides are efficiently absorbed by Na-dependent transport across the intestinal brush border membrane in veal calves. J. Dairy Sci. 85:2308-2314.

Torres-Medina, A., D. H. Schlafer, and C. A. Mebus. 1985. Rotaviral and coronaviral diarrhea. Vet. Clin. North Am. Food Anim. Pract. 1:471-493.

Uauy, R., G. Stringel, R. Thomas, and R. Quan. 1990. Effect of dietary nucleosides on growth and maturation of the developing gut in the rat. J. Pediatr. Gastroenterol. Nutr. 10:497-503.

USDA. 2002. Part I: Reference of dairy health and management in the United States, 2002. Natl. Anim. Health Monit. Syst., Fort Collins, $\mathrm{CO}$

Valdes, R., M. A. Ortega, F. J. Casado, A. Felipe, A. Gil, A. SanchezPozo, and M. Pastor-Anglada. 2000. Nutritional regulation of nucleoside transporter expression in rat small intestine. Gastroenterology 119:1623-1630.

Weiser, M. M. 1973. Intestinal epithelial cell surface membrane glycoprotein synthesis. I. An indicator of cellular differentiation. J. Biol. Chem. 248:2536-2541. 